\title{
First report of Litylenchus coprosma on Coprosma robusta
}

\author{
Yu Mei Xu ${ }^{1,3} \cdot$ Dongmei $\mathrm{Li}^{2} \cdot$ Wellcome $\mathrm{Ho}^{2} \cdot$ Brett J. R. Alexander ${ }^{2}$ Zeng Qi Zhao ${ }^{1,3}$
}

Received: 1 March 2017 / Accepted: 23 March 2017 /Published online: 29 March 2017

(C) Australasian Plant Pathology Society Inc. 2017

\begin{abstract}
Litylenchus coprosma is reported for the first time from Coprosma robusta at two locations in Wellington, New Zealand. Nematodes were isolated from the leaves with angular yellow patches limited by veins and identified as L. coprosma based on morphology and sequence analysis of the SSU and LSU regions of rDNA.
\end{abstract}

Keywords Yellow patch $\cdot$ Nematode $\cdot$ New Zealand . Disease $\cdot$ New host $\cdot$ SSU $\cdot$ LSU

Litylenchus coprosma was first described as a new species from the leaves of Coprosma repens (Maori common name: taupata), from an amenity planting in Wellington, New Zealand (Zhao et al. 2011). On 10 Oct. 2012, angular yellow patches limited by veins were observed on the leaves of another plant, Coprosma robusta (Maori common name: karamu; Fig. 1) from Taylor Park, Tawa, Wellington, New Zealand (E: 1,753,272; N: 5,439,995). Subsequently, the same symptoms were also observed on C. robusta from Cambridge Terrace, Naenae, Lower Hutt, Wellington (E: 1,762,670; N: $5,437,032)$ in 2015. Additional symptomatic leaves were collected from both sites in Tawa and Lower Hutt in 2016. All the leaf samples collected were dissected and observed under

Zeng Qi Zhao

zhaoz@landcareresearch.co.nz

1 Laboratory of Nematology, Department of Plant Pathology, Agronomy College, Shanxi Agricultural University, TaiGu 030801, China

2 Plant Health and Environment Laboratory, Ministry for Primary Industries, PO Box 2095, Auckland 1140, New Zealand

3 Landcare Research, Private Bag 92170, Auckland Mail Centre, Auckland 1142, New Zealand microscope, nematodes were extracted from the symptomatic leaves, but not from the healthy leaves. In one leaf, all life stages of $L$. coprosma were found in the mesophyll, indicating that the life cycle is completed within the leaves. The robust form of the stylet of the nematode suggests that it is a plant feeder (Fig. 2). No cavities, swellings or abnormal growths and no development of nutritive tissue were observed in the leaves (Fig. 1). No fungal hyphae were observed in the leaves of $C$. robusta and no plant pathogenic fungi and bacteria were isolated from the leaves. This indicates that the nematode was likely the primary cause of the discoloration of the leaves. This nematode was identified as L. coprosma by morphology and DNA sequence analysis.

The morphology of this nematode from $C$. robusta matched the descriptions of $L$. coprosma from $C$. repens given by Zhao et al. (2011) (Table 1). However, the main differences between the two populations are the body length, the postuterine sac length and the de Man a ratio (Table 1). The differences could be caused by the host variation and environmental factors. L. coprosma is morphologically characterised by having slender males and females with head offset and distinctly narrower than body diameter (Fig 2a, e). It has a short robust stylet with rounded knobs (Fig 2a,e), pharynx with a weak non-muscular median bulb and glands in a terminal bulb which adjoins the intestine (Fig. 2b), secretory/ excretory pore opening posterior to nerve ring (Fig. 2c), females with a monoprodelphic and post-uterine sac (Fig. 2d), males with arcuate spicules and an adanal bursa that extends nearly to the tail tip (Fig. 2g). Both males and females are living inside the leaves of $C$. robusta and they do not induce galls (Fig. 1). Permanent slides of the L. coprosma specimens were stored in the National Nematode Collection New Zealand, with the collection numbers of NNCNZ3255.

To confirm the morphological identification, the nematodes collected from Tawa were used for DNA extraction. Individual 


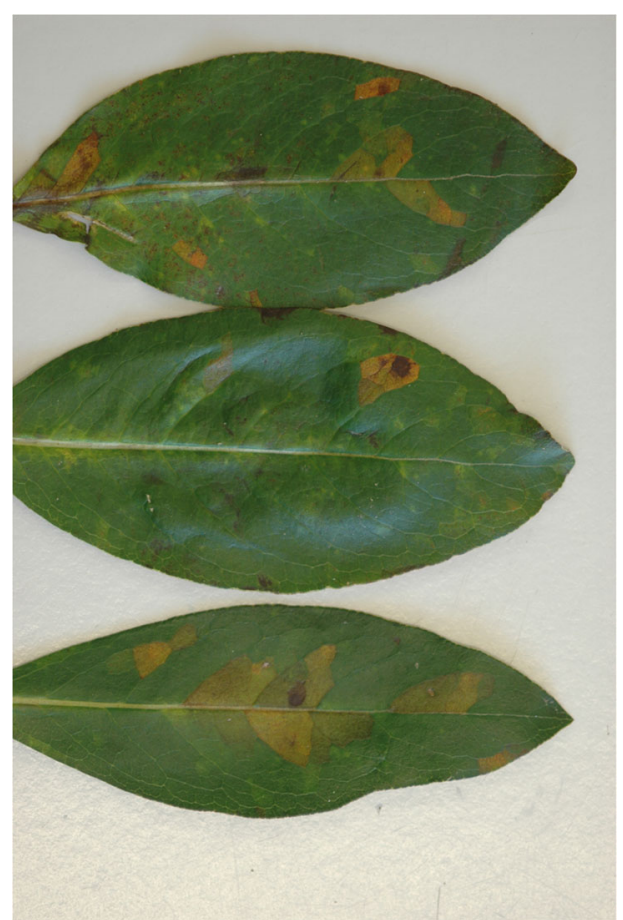

Fig. 1 Yellow patches on leaves of Coprosma robusta infected with Litylenchus coprosma live nematodes were lysed in a buffer of $20 \mu \mathrm{l}$ containing proteinase K (Williams et al. 1992) and DNA was extracted using the method of Zheng et al. (2002). Extracted DNA was used for PCR amplification of nearly full length of small subunit (SSU) rDNA gene with two sets of primers, 1096F/1912R and 1813F/ 2646R (Holterman et al. 2006). Primers, D2A and D3B (Nunn 1992) were used to amplify the D2/D3 expansion segments of the large subunit (LSU) rDNA gene. The PCR compositions and cycling conditions for the amplification of the SSU and LSU genes, and sequencing were conducted as per Zhao et al. (2011, 2013). The sequences from SSU and LSU regions were $99 \%$ similar to sequences of $L$. coprosma in the GenBank (GU727546 SSU, GU727547 LSU). There are 6 SNPs out of $1537 \mathrm{bp}$ for SSU and 2 SNPs out of $713 \mathrm{bp}$ for D2D3 fragment of the LSU between L. coprosma from C. repens and C. robusta, indicating there are slight differences between L. coprosma species from these two hosts. Furthermore, L. coprosma shared $99 \%$ similarity with Subanguina radicicola at the SSU (AF202164, 10/1537 and EU682392, 13/1537), but only $93 \%$ similarity at LSU (DQ328721), suggesting that LSU gene is a better marker to separate these two species. The sequences were submitted to GenBank under the accession numbers KY679563 for SSU and KY679564 for LSU.
Fig. 2 Light microscope photographs of Litylenchus coprosma isolated from leaves of Coprosma robusta. a: Female anterior part and stylet; b: Female oesophagus and intestine junction; c: Female anterior part and excretory pore; $\mathbf{d}$ : Female vulva and genital track; E: Male anterior part and stylet; f: Female tail; g: Male spicules and bursa. (All scale bars $=10 \mu \mathrm{m}$ )
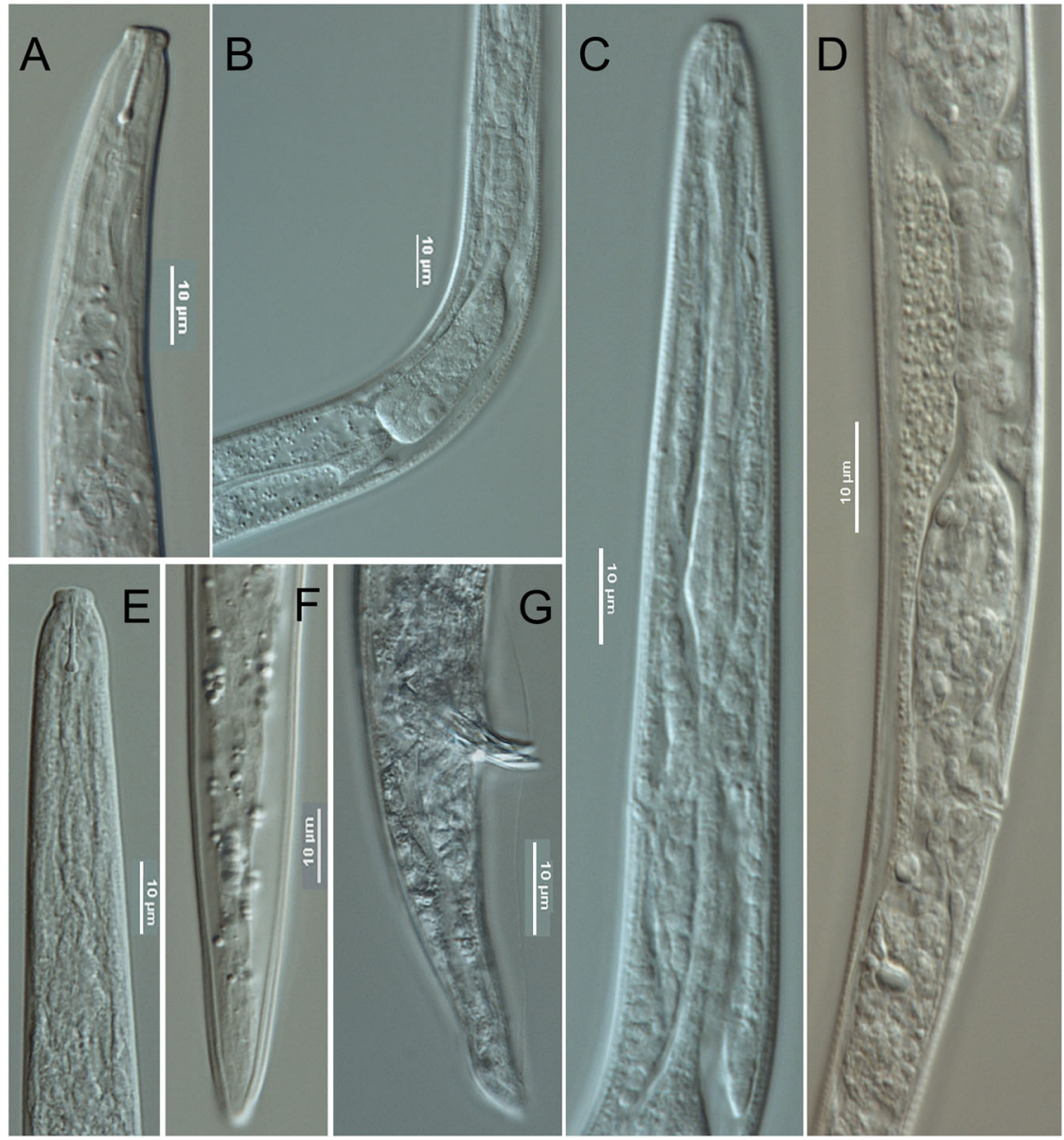
Table 1 Comparative morphometrics of Litylenchus coprosma from Coprosma robusta and C. repens. All measurements given as mean ( $\mu$ m) \pm s.d. (range)

\begin{tabular}{|c|c|c|c|c|c|c|}
\hline \multirow[t]{2}{*}{ Character } & \multicolumn{4}{|l|}{ Female } & \multicolumn{2}{|l|}{ Male } \\
\hline & $\begin{array}{l}\text { C. robusta } \\
\text { (this study) }\end{array}$ & $\begin{array}{l}\text { C. repens } \\
\text { (Zhao et al. 2011) }\end{array}$ & $\begin{array}{l}\text { C. robusta } \\
\text { (this study) }\end{array}$ & $\begin{array}{l}\text { C. repens } \\
\text { (Zhao et al. 2011) }\end{array}$ & $\begin{array}{l}\text { C. robusta } \\
\text { (this study) }\end{array}$ & $\begin{array}{l}\text { C. repens } \\
\text { (Zhao et al. 2011) }\end{array}$ \\
\hline $\mathrm{n}$ & 7 (slender) & 13 (slender) & 5 (obese) & 15 (obese) & 5 & 15 \\
\hline $\mathrm{L}$ & $\begin{array}{l}602 \pm 44 \\
(547-661)\end{array}$ & $\begin{array}{l}743 \pm 50 \\
(649-816)\end{array}$ & $\begin{array}{l}653 \pm 62 \\
(586-721)\end{array}$ & $\begin{array}{l}856 \pm 72 \\
(710-940)\end{array}$ & $\begin{array}{l}647 \pm 25 \\
(617-669)\end{array}$ & $\begin{array}{l}899 \pm 66 \\
(768-994)\end{array}$ \\
\hline $\mathrm{a}$ & $\begin{array}{l}49.9 \pm 5.6 \\
(41.8-58.4)\end{array}$ & $\begin{array}{l}55.2 \pm 4.0 \\
(51.5-63.3)\end{array}$ & $\begin{array}{l}35.7 \pm 5.1 \\
(31.1-43.5)\end{array}$ & $\begin{array}{l}32.8 \pm 3.7 \\
(24.9-37.7)\end{array}$ & $\begin{array}{l}46.5 \pm 7.6 \\
(37.7-56.3)\end{array}$ & $\begin{array}{l}52.0 \pm 4.4 \\
(44.5-60.2)\end{array}$ \\
\hline $\mathrm{b}$ & $\begin{array}{l}4.1 \pm 0.6 \\
(3.4-5.3)\end{array}$ & $\begin{array}{l}4.4 \pm 0.6 \\
(3.9-5.8)\end{array}$ & $\begin{array}{l}4.1 \pm 0.8 \\
(3.4-5.0)\end{array}$ & $\begin{array}{l}5.1 \pm 0.6 \\
(4.2-6.8)\end{array}$ & $\begin{array}{l}5.1 \pm 0.6 \\
(4.3-5.6)\end{array}$ & $\begin{array}{l}5.4 \pm 0.4 \\
(4.8-6.2)\end{array}$ \\
\hline $\mathrm{c}$ & $\begin{array}{l}15.6 \pm 1.4 \\
(13.3-17.1)\end{array}$ & $\begin{array}{l}18.7 \pm 1.3 \\
(16.3-21.3)\end{array}$ & $\begin{array}{l}14.9 \pm 1.6 \\
(12.6-16.5)\end{array}$ & $\begin{array}{l}19.4 \pm 2.5 \\
(15.4-25.0)\end{array}$ & $\begin{array}{l}16.4 \pm 1.8 \\
(14.6-18.9)\end{array}$ & $\begin{array}{l}21.1 \pm 1.9 \\
(18.2-24.1)\end{array}$ \\
\hline$c^{\prime}$ & $\begin{array}{l}4.7 \pm 0.2 \\
(4.3-5.0)\end{array}$ & $\begin{array}{l}4.0 \pm 0.4 \\
(4.0-5.4)\end{array}$ & $\begin{array}{l}4.6 \pm 0.3 \\
(4.3-5.0)\end{array}$ & $\begin{array}{l}3.8 \pm 0.4 \\
(2.9-4.7)\end{array}$ & $\begin{array}{l}3.5 \pm 0.1 \\
(3.4-3.6)\end{array}$ & $\begin{array}{l}3.5 \pm 0.4 \\
(3.1-4.4)\end{array}$ \\
\hline $\mathrm{V} / \mathrm{T}$ & $\begin{array}{l}80.8 \pm 1.0 \\
(79.0-82.3)\end{array}$ & $\begin{array}{l}81.5 \pm 2.4 \\
(76.5-85.3)\end{array}$ & $\begin{array}{l}81.0 \pm 1.6 \\
(78.8-82.8)\end{array}$ & $\begin{array}{l}82.2 \pm 1.6 \\
(78.8-84.7)\end{array}$ & $\begin{array}{l}55.8 \pm 7.2 \\
(49.3-63.5)\end{array}$ & $\begin{array}{l}73.0 \pm 6.6 \\
(60.7-82.1)\end{array}$ \\
\hline Max. body diam. & $\begin{array}{l}12.2 \pm 1.3 \\
(10.9-14.5)\end{array}$ & $\begin{array}{l}13.5 \pm 0.6 \\
(12.6-14.6)\end{array}$ & $\begin{array}{l}18.4 \pm 2.0 \\
(16.2-21.1)\end{array}$ & $\begin{array}{l}26.3 \pm 3.1 \\
(22.5-33.9)\end{array}$ & $\begin{array}{l}14.3 \pm 1.9 \\
(11.9-16.9)\end{array}$ & $\begin{array}{l}17.3 \pm 1.3 \\
(15.8-20.3)\end{array}$ \\
\hline Stylet length & $\begin{array}{l}10.2 \pm 0.7 \\
(9.2-10.9)\end{array}$ & $\begin{array}{l}10.8 \pm 0.9 \\
(8.9-11.7)\end{array}$ & $\begin{array}{l}10.0 \pm 0.5 \\
(9.6-10.6)\end{array}$ & $\begin{array}{l}10.9 \pm 0.3 \\
(10.2-11.4)\end{array}$ & $\begin{array}{l}10.2 \pm 0.9 \\
(9.5-11.5)\end{array}$ & $\begin{array}{l}10.5 \pm 0.5 \\
(9.7-11.3)\end{array}$ \\
\hline Excretory pore from anterior end & $\begin{array}{l}90.3 \pm 2.2 \\
(86.4-93.0)\end{array}$ & $\begin{array}{l}113 \pm 6.0 \\
(101-115)\end{array}$ & $\begin{array}{l}91.3 \pm 13.4 \\
(79.6-106)\end{array}$ & $\begin{array}{l}99 \pm 13 \\
(81-104)\end{array}$ & $\begin{array}{l}88.1 \pm 4.7 \\
(82.6-91.1)\end{array}$ & $\begin{array}{l}111 \pm 9.0 \\
(96-121)\end{array}$ \\
\hline Spicule length & - & - & - & - & $\begin{array}{l}14.3 \pm 1.3 \\
(13.0-15.9)\end{array}$ & $\begin{array}{l}16.2 \pm 0.7 \\
(14.9-17.0)\end{array}$ \\
\hline Post-uterine sac length & $\begin{array}{l}18.8 \pm 2.4 \\
(14.8-21.3)\end{array}$ & $\begin{array}{l}22.4 \pm 6.8 \\
(11.4-35.0)\end{array}$ & $\begin{array}{l}17.7 \pm 1.9 \\
(15.6-20.0)\end{array}$ & $\begin{array}{l}34.9 \pm 9.5 \\
(24.1-48.5)\end{array}$ & - & - \\
\hline Tail length & $\begin{array}{l}38.7 \pm 1.5 \\
(36.4-41.1)\end{array}$ & $\begin{array}{l}40.1 \pm 4.0 \\
(32.2-46.3)\end{array}$ & $\begin{array}{l}45.1 \pm 1.7 \\
(42.9-46.5)\end{array}$ & $\begin{array}{l}45.1 \pm 6.6 \\
(31.2-55.1)\end{array}$ & $\begin{array}{l}39.8 \pm 3.2 \\
(35.3-43.7)\end{array}$ & $\begin{array}{l}42.8 \pm 3.6 \\
(37.1-50.7)\end{array}$ \\
\hline Anal/Cloacal body diam. & $\begin{array}{l}8.3 \pm 0.4 \\
(7.9-9.1)\end{array}$ & $\begin{array}{l}8.7 \pm 0.6 \\
(7.6-9.6)\end{array}$ & $\begin{array}{l}9.9 \pm 0.7 \\
(9.2-10.9)\end{array}$ & $\begin{array}{l}11.7 \pm 0.9 \\
(10.4-12.8)\end{array}$ & $\begin{array}{l}11.4 \pm 1.1 \\
(9.9-12.7)\end{array}$ & $\begin{array}{l}12.3 \pm 0.5 \\
(11.4-12.9)\end{array}$ \\
\hline
\end{tabular}

Fig. 3 Bayesian phylogenetic tree inferred from sequences of the D2D3 fragment of LSU gene. Posterior probabilities greater than $50 \%$ are given on appropriate clades. Nematode species and GenBank Accession numbers are listed for each taxon

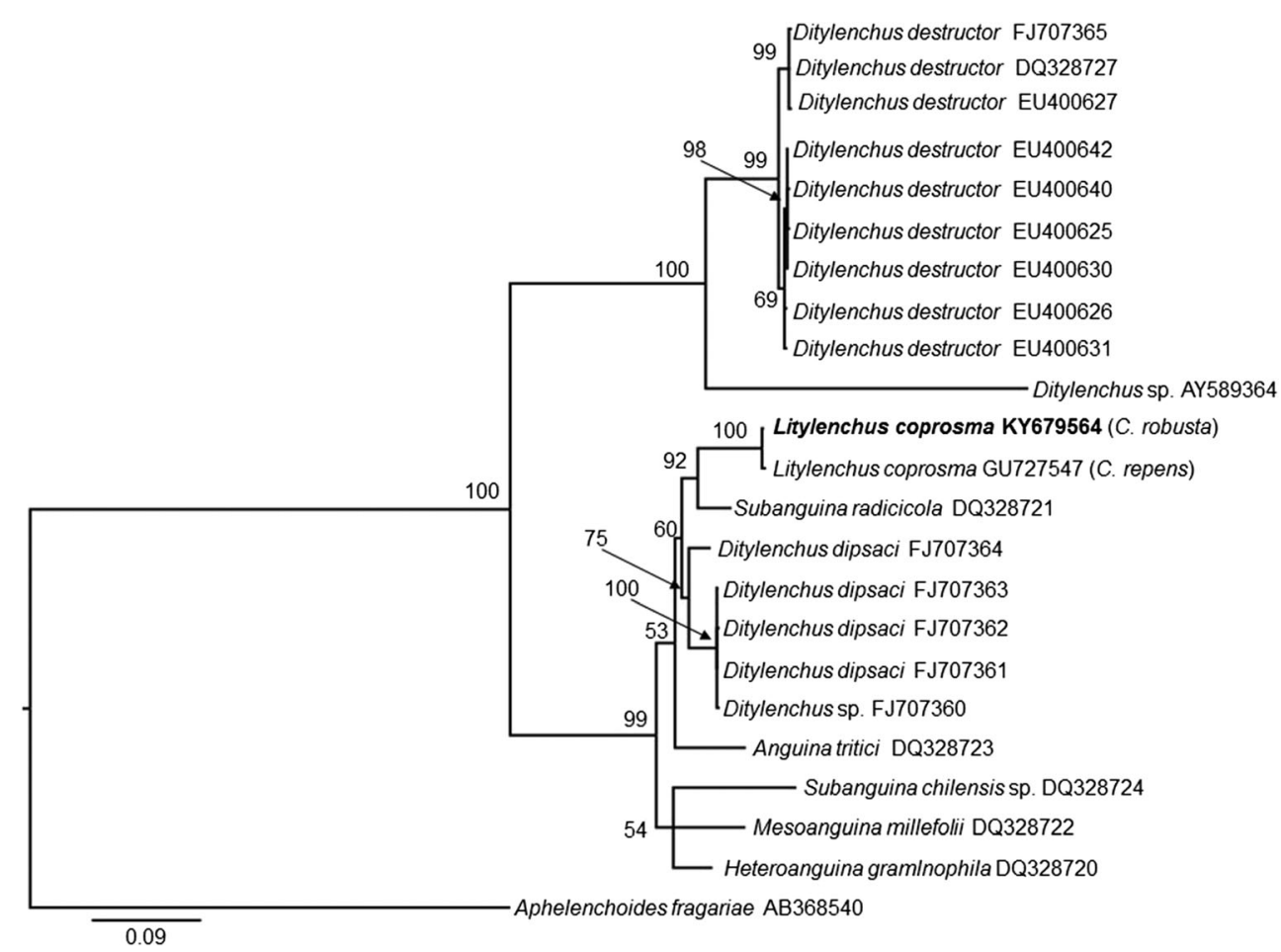


To further resolve the phylogenetic relationship, the D2/D3 region of the 28S rRNA sequences derived from $L$. coprosma from $C$. robusta was used to construct phylogenetic tree. The related LSU sequences were aligned with ClustalX in Geneious 10.0.6 (http://www.geneious.com, Kearse et al. 2012) using the default parameter values. A Bayesian tree was constructed with MrBayes in Geneious using substitution model GTR and rate vitiation gamma. The tree was rooted using Aphelenchoides fragariae as the out group. The phylogenetic tree showed that $L$. coprosma derived from $C$. robusta formed a clade with $L$. coprosma of $C$. repens with $100 \mathrm{pp}$. value support, and well distant from the other genera (Fig. 3).

There are around 90 species of Coprosma (family: Rubiaceae) distributed mainly in the Pacific and Australasia. Among these, 58 species are endemic to New Zealand (New Zealand conservation network 2013). Both C. repens and C. robusta are native to New Zealand, common in the forest and costal region of both North and South islands. They are also common ornamental plants. Coprosma are generally pest free, occasionally infected by root rot and scale insects (Polizzi et al. 2009). However, a number of fungal diseases have been reported: Rhizoctonia solani AG-4 strain causing root rot in C. repens and C. lucida in nurseries in Italy (Polizzi et al. 2009); Puccinia coprosmae causing leaf spot in several Coprosma species, including C. repens and C. robusta (Hood 2010); and Cercospora and Coniothyrium causing leaf spotting and blight, respectively (Ridley et al. 2000). The symptoms caused by L coprosma are different from those caused by fungi, and no mycelia were observed in yellow patches leaves of C. robusta.

There were four species of nematodes, Blandicephalanema pilatum, Helicotylenchus erythrinae, H. labiatus, and H. minzi associated with Coprosma trees in the rhizosphere (Knight et al. 1997), but these nematodes have not been reported to cause disease symptoms on the trees. L. coprosma was not found in the soil collected under the infested $C$. repens and C. robusta trees.

In conclusion, this is the first report of $L$. coprosma causing yellow patches on $C$. robusta following the initial description of this nematode on $C$. repens. The yellow patches caused by $L$. coprosma were observed in the leaves of $C$. repens and C. robusta. Further sampling of other Coprosma species are needed to investigate the host distribution of $L$. coprosma in New Zealand.
Acknowledgements We thank Brent Rogan (SPS Biosecurity Ltd., New Zealand) for collecting C. robusta samples, Ewen Cameron (Curator Botany, Auckland War Memorial Museum, New Zealand) for confirmation of $C$. robusta identity. This research was supported by core funding for Crown Research Institutes from the Ministry of Business, Innovation and Employment's Science and Innovation Group.

\section{References}

Holterman M, Van Der Wurff A, van den Elsen S, van Megen H, Bongers T, Holovacgov O, Bakker J, Helder J (2006) Phylum-wide analysis of SSU rDNA reveals deep phylogenetic relationships among nematodes and accelerated evolution toward crown clades. Mol Biol Evol 13:1792-1800

Hood IA (2010) Rust fungi in native forests, in Forest pathology in New Zealand No:14

Kearse M, Moir R, Wilson A, Stones-Havas S, Cheung M, Sturrock S, Buxton S, Cooper A, Markowitz S, Duran C, Thierer T, Ashton B, Mentjies P, Drummond A (2012) Geneious basic: an integrated and extendable desktop software platform for the organization and analysis of sequence data. Bioinformatics 28:1647-1649

Knight KW, Barber CJ, Page GD (1997) Plant-parasitic nematodes of New Zealand recorded by host association. Supplement to the Journal of Nematology 29:640-656

New Zealand plant conservation network (2013) Coprosma. http://wwwnzpcnorgnz/pageaspx?flora_vascular_flowering plants_dicots_coprosma Accessed 28 February 2013

Nunn GB (1992) Nematode molecular evolution. Ph.D. Thesis, University of Nottingham, Nottingham

Polizzi G, Aiello D, Castello I, Vitale A (2009) First report of crown and root rot caused by Rhizoctonia solani AG-4 on Coprosma repens and C. lucida in Italy. Plant Dis 93:972-972

Ridley GS, Bain J, Bulman LS, Dick MA, Kay MK (2000) Threats to New Zealand's indigenous forests from exotic pathogens and pests. Science for conservation 142. Published by Department for Conservation, Wellington

Williams BD, Schrank B, Huynh C, Shownken R, Waterston RH (1992) A genetic mapping system in Caenorhabditis elegans based on polymorphic sequence-tagged sites. Genetics 131:609-624

Zhao ZQ, Davies K, Alexander B, Riley IT (2011) Litylenchus coprosma gen. N., sp. n. (Tylenchida: Anguinata), from leaves of Coprosma repens (Rubiaceae) in New Zealand. Nematology 13:29-44

Zhao ZQ, Davies K, Alexander B, Riley IT (2013) Zeatylenchus pittosporum gen. N., sp. n. (Tylenchida: Anguinata), from leaves of Pittosporum tenuifolium (Pittosporaceae) in New Zealand. Nematology 15:172-212

Zheng JW, Subbotin SA, He SS, Gu JF, Moens M (2002) Molecular characterisation of some Asian isolates of Bursaphelenchus xylophilus and B. mucronatus using PCR-RFLPs and sequences of ribosomal DNA. Russ J Nematol 11:17-22 